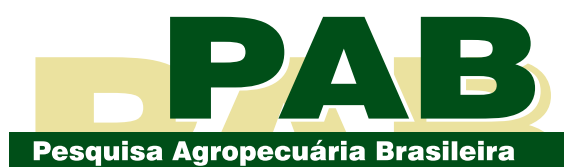

ISSN 1678-3921

Journal homepage: www.embrapa.br/pab

For manuscript submission and journal contents, access: www.scielo.br/pab
Pomology/ Original Article

\section{Yield and must composition of grapevines subjected to phosphate fertilization in Southern Brazil}

\begin{abstract}
The objective of this work was to evaluate the yield and must composition of 'Cabernet Sauvignon' and 'Chardonnay' grapevines subjected to phosphorus applications to a soil from a high-altitude region of Southern Brazil, during three crop seasons. Experiments 1 and 2 were carried out in 'Cabernet Sauvignon' and 'Chardonnay' commercial vineyards, respectively, in the municipality of Água Doce, located in the Midwestern region of the state of Santa Catarina. The soil from the two vineyards was classified as a Typic Humicryept. The used source of $\mathrm{P}$ was triple superphosphate $(45 \%$ $\mathrm{P}_{2} \mathrm{O}_{5}$ ). From 2011 to 2013, at flowering, a total of 0, 10, 20, 40, and $80 \mathrm{~kg}$ $\mathrm{ha}^{-1} \mathrm{P}_{2} \mathrm{O}_{5}$ were applied in the crown projection area, to the soil surface, without incorporation, in both vineyards. Soil and leaf $\mathrm{P}$ concentration, yield parameters, and must quality were evaluated. The increase in $P$ availability decreased total titratable acidity and tartaric acid in the must of the 'Cabernet Sauvignon' grapevine in the 2013/2014 crop season and increased $\mathrm{pH}$ and total soluble solids in the must of the 'Chardonnay' grapevine in the 2011/2012 crop season. Phosphorus application to the soil increases the levels of available phosphorus, but does not result in higher yields for 'Cabernet Sauvignon' and 'Chardonnay' grapevines.
\end{abstract}

Index terms: Vitis vinifera, available phosphorus, 'Cabernet Sauvignon', 'Chardonnay', high altitude.

\section{Produtividade e composição do mosto de videiras submetidas à adubação fosfatada no Sul do Brasil}

Resumo - O objetivo deste trabalho foi avaliar a produtividade e a composição do mosto de videiras 'Cabernet Sauvignon' e 'Chardonnay' submetidas a aplicações de fósforo em solo de região de altitude no Sul do Brasil, durante três safras. Os experimentos 1 e 2 foram realizados em vinhedos comerciais de 'Cabernet Sauvignon' e de 'Chardonnay', respectivamente, no município de Água Doce, na região Meio-Oeste do estado de Santa Catarina. O solo dos dois vinhedos foi classificado como Cambissolo Húmico. A fonte de P utilizada foi o superfosfato triplo $\left(45 \%\right.$ de $\left.\mathrm{P}_{2} \mathrm{O}_{5}\right)$. De 2011 a 2013, no florescimento, foram aplicados $0,10,20,40$ e $80 \mathrm{~kg} \mathrm{ha}^{-1}$ de $\mathrm{P}_{2} \mathrm{O}_{5}$ na projeção da copa, na superfície do solo, sem incorporação, em ambos os vinhedos. Avaliaram-se concentração de $\mathrm{P}$ no solo e na folha, variáveis de produção e qualidade do mosto. $\mathrm{O}$ incremento na disponibilidade de $\mathrm{P}$ diminuiu os valores de acidez total titulável e de ácido tartárico no mosto da videira 'Cabernet Sauvignon' na safra de 2013/2014 e aumentou os valores de pH e sólidos solúveis totais no mosto da videira 'Chardonnay' na safra de 2011/2012. A aplicação de fósforo no solo aumenta os níveis de fósforo disponível, mas não resulta em maiores produtividades das videiras 'Cabernet Sauvignon' e 'Chardonnay'. 
Termos para indexação: Vitis vinifera, fósforo disponível, 'Cabernet Sauvignon', 'Chardonnay', alta altitude.

\section{Introduction}

Brazilian vineyards (Vitis vinifera L.) are typically found on clayey soils, characterized by a predominance of 1:1 silicate minerals and iron and aluminum oxyhydroxides in the clay fraction, which are naturally poor in phosphorus (Almeida et al., 2018). Due to these characteristics, these soils exhibit a high $\mathrm{P}$ adsorption affinity at different energy levels, and most of the $\mathrm{P}$ is retained with a high degree of binding energy (Oliveira et al., 2014). Therefore, only a small part of the $P$ present in the soil is available to plants (Simões Neto et al., 2009), justifying the application of phosphate fertilizers in these vineyards.

There is an accumulation of organic matter (Bonfatti et al., 2016) and organic P (Schmitt et al., 2017) in the soil of vineyards located at altitudes between 900 and $1,400 \mathrm{~m}$. The organic forms of $\mathrm{P}$ in the soil can be mineralized, increasing the inorganic $\mathrm{P}$ fractions in the soil, some of which are absorbed by the plants (Rita et al., 2013). Part of the P absorbed by the grapevines is cycled through the deposition and decomposition of pruned leaves and branches, the deposition of cover crop shoots, and the senescence of grapevine roots and cover crop species (Schreiner, 2005; Tecchio et al., 2011). Another part is transported and accumulated in perennial reserve organs, such as roots (Gautier et al., 2018). Grapevine roots can be colonized by arbuscular mycorrhizal fungi, which can increase the volume of soil explored by the root system, enhancing water and nutrient uptake (Schreiner, 2005). However, despite decreasing the demand of grapevines for $\mathrm{P}$ applied to the soil, all these sources are probably not enough to meet total plant demand, supporting the need for $\mathrm{P}$ application to reach the desired yield and grape quality.

There is still a lack of information on the most adequate $P$ rates for grapevine cultivars due to their different $\mathrm{P}$ uptake efficiencies and potentials for $\mathrm{P}$ accumulation within the plant and for $\mathrm{P}$ export by the clusters (Tecchio et al., 2011; Schreiner et al., 2013). This is especially true in clayey soils with a high organic matter content. The critical levels of soil or leaf $\mathrm{P}$ are also not known, nor is the real impact of phosphate fertilization on yield parameters and must composition (Poni et al., 2018). However, this information is obtainable in field experiments, preferably conducted for more than one crop season.

In Brazil, little is known about responses to $\mathrm{P}$ fertilization in grapevines. The Cabernet Sauvignon and Chardonnay cultivars stand out because of their suitable characteristics for the production of the fine quality wines - red and white, respectively - commonly grown in the high-altitude regions of Southern Brazil (Brighenti et al., 2013). It is believed that these cultivars may have different kinetic parameters related to $\mathrm{P}$ absorption, which may reflect in their different responses to fertilization (Piccin et al., 2017a).

The objective of this work was to evaluate the yield and must composition of 'Cabernet Sauvignon' and 'Chardonnay' grapevines subjected to phosphorus applications to a soil from a high-altitude region of Southern Brazil, during three crop seasons.

\section{Materials and Methods}

Two experiments were conducted, each in a commercial vineyard in the municipality of Água Doce, located in the Midwestern region of the state of Santa Catarina, Southern Brazil. The climate of the region is temperate oceanic $(\mathrm{Cfb})$ with mild summers, according to Köppen-Geiger's classification. The number of accumulated cold hours equal to or below $7.2^{\circ} \mathrm{C}$ ranges from 642 to 778 per year. Data of average air temperature and precipitation are shown in Figure 1. The soil from both vineyards was classified as a Cambissolo Húmico (Santos et al., 2013), i.e., a Typic Humicryept (Soil Survey Staff, 2010).

The first vineyard $\left(26^{\circ} 42^{\prime} 10^{\prime \prime} \mathrm{S}, 51^{\circ} 43^{\prime} 49^{\prime \prime} \mathrm{W}\right.$, at 1,250 $m$ altitude) was installed in 2004 using the 'Cabernet Sauvignon' grapevine ( $V$. vinifera) grafted onto the 'Paulsen 1103' rootstock (Vitis berlandieri Planch. $\mathrm{x}$ Vitis rupestris Scheele). The vines were trained in the vertical shoot position (VSP) system and spaced 2.9x1.5 m apart, totaling 2,299 plants per hectare. The soil of this vineyard had the following chemical and physical characteristics at $0-20-\mathrm{cm}$ depth prior to the installation of the experiment: $445 \mathrm{~g} \mathrm{~kg}^{-1}$ clay (Pipette method); $63 \mathrm{~g} \mathrm{~kg}^{-1}$ organic matter (WalkleyBlack method); $6.1 \mathrm{pH}$ in water (1:1 ratio); 6.9 and 4.7 $\mathrm{cmol}_{\mathrm{c}} \mathrm{kg}^{-1} \mathrm{Ca}$ and $\mathrm{Mg}(\mathrm{KCl} 1 \mathrm{~mol} \mathrm{~L}-1)$, respectively; and 7.2 and $260 \mathrm{mg} \mathrm{kg}^{-1}$ available $\mathrm{P}$ and $\mathrm{K}$ (Mehlich 1), respectively (Tedesco et al., 1995). 
The second vineyard $\left(26^{\circ} 43^{\prime} 41^{\prime \prime} \mathrm{S}, \quad 51^{\circ} 31^{\prime} 25^{\prime \prime} \mathrm{W}\right.$, at $1,200 \mathrm{~m}$ altitude) was installed in 2003 using the 'Chardonnay' ( $V$. vinifera) grapevine also grafted onto the 'Paulsen 1103' rootstock. Likewise, the vines were trained in the VSP system and spaced $2.9 \times 1.5 \mathrm{~m}$ apart, totaling 2,299 plants per hectare. The soil of this vineyard had the following chemical and physical characteristics at $0-20-\mathrm{cm}$ depth prior to the installation of the experiment: $452 \mathrm{~g} \mathrm{~kg}^{-1}$ clay (Pipette method); $62.4 \mathrm{~g} \mathrm{~kg}^{-1}$ organic matter (Walkley-Black method); $6.1 \mathrm{pH}$ in water (1:1 ratio); 7.1 and $5.8 \mathrm{cmol}_{\mathrm{c}}$ $\mathrm{dm}^{-3} \mathrm{Ca}$ and $\mathrm{Mg}\left(\mathrm{KCl} 1 \mathrm{~mol} \mathrm{~L}^{-1}\right)$, respectively; and 2.3 and $122 \mathrm{mg} \mathrm{kg}^{-1}$ available $\mathrm{P}$ and $\mathrm{K}$ (Mehlich 1), respectively (Tedesco et al., 1995).

Both vineyards were pruned by the spur-pruned cordon system in late winter. Vegetation between planting rows was predominantly composed of white clover (Trifolium repens L.), ryegrass (Lolium multiflorum Lam.), and tall fescue (Festuca arundinacea Schreb.), which were mowed to $10 \mathrm{~cm}$ of height every 50 days or so. Plant residues were deposited on soil surface.

In both vineyards, from 2011 to 2013, 0, 10, 20, 40 , and $80 \mathrm{~kg} \mathrm{ha}^{-1} \mathrm{P}_{2} \mathrm{O}_{5}$ were applied at flowering, in the crown projection area, to the soil surface, without incorporation. The source of $\mathrm{P}$ was triple superphosphate $\left(\begin{array}{lll}45 \% & \mathrm{P}_{2} \mathrm{O}_{5}\end{array}\right)$. The experimental design used in both experiments was of randomized

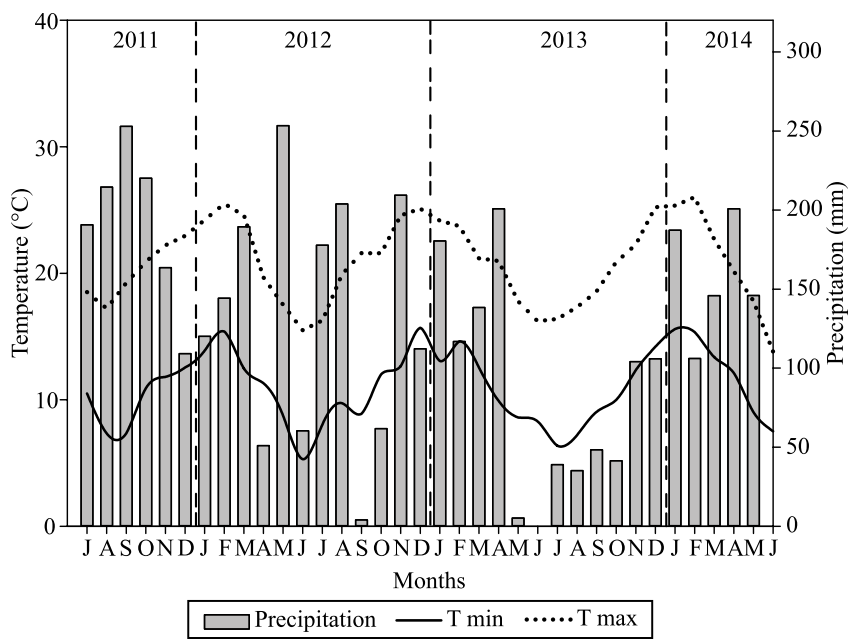

Figure 1. Precipitation, average maximum temperature ( $T$ max), and average minimum temperature ( $\mathrm{T} \mathrm{min}$ ) from July 2011 to June 2014 in the municipality of Água Doce, in the state of Santa Catarina, Brazil. complete blocks with four replicates. Each plot consisted of five plants, of which the three central ones were evaluated.

Soil samples at the $0-20-\mathrm{cm}$ depth were collected at full flowering and veraison (onset of maturation). The soil was air-dried, ground, and passed through a 2-mm sieve, and available $\mathrm{P}$ was determined (Mehlich 1) according to Murphy \& Riley (1962). At full flowering and veraison, ten mature leaves were collected per plant in the middle third of the shoot each year. The leaves were dried in a forced-air oven, at $65^{\circ} \mathrm{C}$, until constant weight, ground, and subjected to sulfuric acid digestion (Tedesco et al., 1995). Phosphorus concentration was determined in the extract, as described by Murphy \& Riley (1962).

The number of fruit clusters per vine was counted at harvest. All clusters were collected and weighed to determine yield. A sample composed of five clusters per vine was evaluated as to mass $(\mathrm{g})$, length $(\mathrm{cm})$, and width $(\mathrm{cm})$.

Three samples with 50 berries each were randomly collected from different clusters and positions. The berries were crushed for the extraction of must, which was collected and subjected to the chemical analysis. The resulting must was used to determine: soluble solids concentration, with the RTD-45 digital refractometer with temperature compensation (Instrutherm, São Paulo, Brazil); total titratable acidity, by titration ( 0.1 $\mathrm{N} \mathrm{NaOH}$ ) with $1 \%$ phenolphthalein; $\mathrm{pH}$, using the AD1030 pH meter (ADWA, Szeged, Hungary); and tartaric acid, by the LC-10A high-performance liquid chromatography equipment (Shimadzu, Kyoto, Japan). In the 2012/2013 crop season, excess rain damaged grape production and, therefore, no assessments were carried out.

The results were subjected to the analysis of variance using the Sisvar, version 5.6, software (Ferreira, 2003). When the effects were significant, regression equations were adjusted by testing the linear and quadratic models with the F-test and then choosing the one with less than $5 \%$ significance $(p<0.05)$. The linear regression model was fitted between leaf $\mathrm{P}$ concentration and grape yield.

\section{Results and Discussion}

In the 'Cabernet Sauvignon' vineyard, available $\mathrm{P}$ content in the soil at flowering increased 0.14 and 0.22 
mg for each kilogram of $\mathrm{P}_{2} \mathrm{O}_{5}$ applied in 2011/2012 and 2012/2013 (Table 1). At veraison, the availability of soil $\mathrm{P}$ increased in $0.17 \mathrm{mg}$ for each kilogram of $\mathrm{P}_{2} \mathrm{O}_{5}$ applied to the soil in both of these crop seasons. Leaf $\mathrm{P}$ concentration at full flowering increased with the application of P rates in 2013/2014, and the highest concentration of $2.5 \mathrm{~g} \mathrm{~kg}^{-1} \mathrm{P}$ was found in the vines that received $50 \mathrm{~kg} \mathrm{ha}^{-1} \mathrm{P}_{2} \mathrm{O}_{5}$. However, leaf $\mathrm{P}$ concentration was not affected by the application of $\mathrm{P}$ rates to the soil at full flowering in 2011/2012, at full flowering and veraison in 2012/2013, and at veraison in 2013/2014. Leaf P concentration at full flowering was inversely correlated to yield (Figure 2), since, for every unit increase in leaf $\mathrm{P}$ concentration, there was an average reduction of $0.6 \mathrm{Mg} \mathrm{ha}^{-1}$ in yield.

In the 'Chardonnay' vineyard, available $\mathrm{P}$ content in the soil at full flowering increased with the application of $\mathrm{P}$ rates in all crop seasons (Table 2). The increase in available $\mathrm{P}$ was $0.14,0.30$, and $0.17 \mathrm{mg} \mathrm{P}$ for each kilogram of $\mathrm{P}_{2} \mathrm{O}_{5}$ in 2011/2012, 2012/2013, and 2013/2014, respectively. Available $\mathrm{P}$ in the soil at veraison increased 0.12 and 0.28 mg P for each kilogram of $\mathrm{P}_{2} \mathrm{O}_{5}$ in $2012 / 2013$ and 2013/2014, respectively. Leaf P concentration at full flowering increased $0.03,0.03$, and $0.04 \mathrm{~g} \mathrm{~kg}^{-1} \mathrm{P}$ for each kilogram of $\mathrm{P}_{2} \mathrm{O}_{5}$ in 2011/2012, 2012/2013, and

Table 1. Soil available phosphorus and total leaf $\mathrm{P}$, number of clusters per plant, average cluster mass, yield, average cluster length, and average cluster width of 'Cabernet Sauvignon' grapevines (Vitis vinifera) grown in a Typic Humicryept subjected to the application of different $\mathrm{P}_{2} \mathrm{O}_{5}$ rates, in the municipality of Água Doce, in the state of Santa Catarina, Brazil.

\begin{tabular}{|c|c|c|c|c|c|c|c|}
\hline \multirow[t]{2}{*}{ Variable } & \multicolumn{5}{|c|}{$\mathrm{P}_{2} \mathrm{O}_{5}\left(\mathrm{~kg} \mathrm{ha}^{-1}\right)$} & \multirow[t]{2}{*}{ Equation } & \multirow[t]{2}{*}{$\mathrm{R}^{2}$} \\
\hline & 0 & 10 & 20 & 40 & 80 & & \\
\hline \multicolumn{8}{|c|}{$2011 / 2012$ crop season } \\
\hline Soil available $\mathrm{P}$ at flowering $\left(\mathrm{mg} \mathrm{kg}^{-1}\right)$ & 7.6 & 7.4 & 9.9 & 10.7 & 18.9 & $y=6.57+0.14 x$ & $0.38 * *$ \\
\hline Soil available $\mathrm{P}$ at veraison $\left(\mathrm{mg} \mathrm{kg}^{-1}\right)$ & - & - & - & - & - & - & - \\
\hline Total leaf $\mathrm{P}$ at flowering $\left(\mathrm{g} \mathrm{kg}^{-1}\right)$ & 2.4 & 2.6 & 2.6 & 2.8 & 2.8 & - & ns \\
\hline Total leaf $\mathrm{P}$ at veraison $\left(\mathrm{g} \mathrm{kg}^{-1}\right)$ & - & - & - & - & - & - & - \\
\hline Number of clusters per plant & 16 & 13 & 12 & 13 & 14 & - & ns \\
\hline Average cluster mass (g) & 218 & 215 & 209 & 228 & 227 & - & ns \\
\hline Yield $\left(\mathrm{Mg} \mathrm{ha}^{-1}\right)$ & 8.0 & 6.8 & 5.8 & 6.6 & 7.3 & - & ns \\
\hline Average cluster length (cm) & 12.5 & 12.3 & 12.6 & 12.4 & 12.4 & - & ns \\
\hline Average cluster width $(\mathrm{cm})$ & 4.8 & 4.6 & 4.6 & 4.5 & 4.9 & - & ns \\
\hline \multicolumn{8}{|c|}{$2012 / 2013$ crop season } \\
\hline Soil available $\mathrm{P}$ at flowering $\left(\mathrm{mg} \mathrm{kg}^{-1}\right)$ & 2.3 & 2.8 & 8 & 8.9 & 20.1 & $y=1.76+0.22 x$ & $0.90 *$ \\
\hline Soil available $\mathrm{P}$ at veraison $\left(\mathrm{mg} \mathrm{kg}^{-1}\right)$ & 3.7 & 6.3 & 8.5 & 11.0 & 18.2 & $\mathrm{y}=4.32+0.17 \mathrm{x}$ & $0.83 * *$ \\
\hline Total leaf $\mathrm{P}$ at flowering $\left(\mathrm{g} \mathrm{kg}^{-1}\right)$ & 4.5 & 6.2 & 5.5 & 5.4 & 5.3 & - & ns \\
\hline Total leaf $\mathrm{P}$ at veraison $\left(\mathrm{g} \mathrm{kg}^{-1}\right)$ & 2.4 & 2.7 & 2.7 & 2.6 & 2.7 & - & ns \\
\hline Number of clusters per plant & 16 & 10 & 11 & 11 & 13 & - & ns \\
\hline Average cluster mass (g) & 69 & 69 & 63 & 74 & 66 & - & ns \\
\hline Yield $\left(\mathrm{Mg} \mathrm{ha}^{-1}\right)$ & 2.6 & 1.6 & 1.5 & 1.8 & 1.9 & - & ns \\
\hline Average cluster length (cm) & 12.5 & 11.3 & 11.6 & 11.4 & 11 & - & ns \\
\hline Average cluster width $(\mathrm{cm})$ & 5.4 & 4.7 & 5.1 & 5.7 & 5.3 & - & ns \\
\hline \multicolumn{8}{|c|}{$2013 / 2014$ crop season } \\
\hline Soil available $\mathrm{P}$ at flowering $\left(\mathrm{mg} \mathrm{kg}^{-1}\right)$ & 0.4 & 0.9 & 1.8 & 2.9 & 9.0 & - & ns \\
\hline Soil available $\mathrm{P}$ at veraison $\left(\mathrm{mg} \mathrm{kg}^{-1}\right)$ & 2.1 & 2.8 & 2.8 & 5.7 & 15.6 & $y=0.90+0.17 x$ & $0.94 * *$ \\
\hline Total leaf $\mathrm{P}$ at flowering $\left(\mathrm{g} \mathrm{kg}^{-1}\right)$ & 2.0 & 2.2 & 2.3 & 2.4 & 2.1 & $y=1.99+0.02 x-0.0002 x^{2}$ & $0.32 *$ \\
\hline Total leaf $\mathrm{P}$ at veraison $\left(\mathrm{g} \mathrm{kg}^{-1}\right)$ & 1.8 & 1.8 & 1.8 & 1.6 & 1.9 & - & ns \\
\hline Number of clusters per plant & 24 & 19 & 20 & 20 & 23 & - & ns \\
\hline Average cluster mass (g) & 119 & 121 & 117 & 128 & 130 & - & ns \\
\hline Yield $\left(\mathrm{Mg} \mathrm{ha}^{-1}\right)$ & 6.8 & 5.2 & 5.3 & 5.9 & 7.0 & - & ns \\
\hline Average cluster length $(\mathrm{cm})$ & 13.8 & 14 & 13.1 & 13.8 & 14.2 & - & ns \\
\hline Average cluster width $(\mathrm{cm})$ & 6.5 & 5.9 & 6.3 & 7.2 & 6.3 & - & ns \\
\hline
\end{tabular}

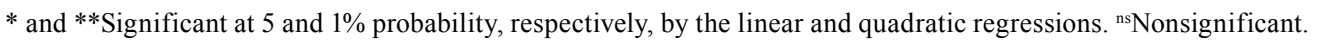


2013/2014, respectively. Similarly to leaf P at full flowering, leaf $\mathrm{P}$ concentrations at veraison increased 0.02 and $0.01 \mathrm{~g} \mathrm{~kg}^{-1} \mathrm{P}$ for each kilogram of $\mathrm{P}_{2} \mathrm{O}_{5}$ in 2012/2013 and 2013/2014. However, unlike 'Cabernet Sauvignon', 'Chardonnay' grapevines showed no significant correlation between leaf $\mathrm{P}$ concentration and grape yield.

Since the soil has a high $\mathrm{P}$ adsorption capacity due to the presence of 1:1 clay minerals and $\mathrm{Fe}$ and $\mathrm{Al}$ oxyhydroxides (Almeida et al., 2018), it is advisable to apply $\mathrm{P}$ in greater amounts than those exported by the plants, ideally up to five applications (Silva et al., 2016). As $P$ was applied in the area of crown projection, i.e., in a reduced area, there was a significant increase in $P$ availability.

The application of $\mathrm{P}$ to the soil increased leaf $\mathrm{P}$ and, consequently, also $P$ availability (Tables 1 and 2). Leaf $\mathrm{P}$ concentrations at full flowering and veraison in the 'Cabernet Sauvignon' and 'Chardonnay' grapevines were considered normal (1.2 to $\left.4.0 \mathrm{~g} \mathrm{~kg}^{-1} \mathrm{P}\right)$ or excessive

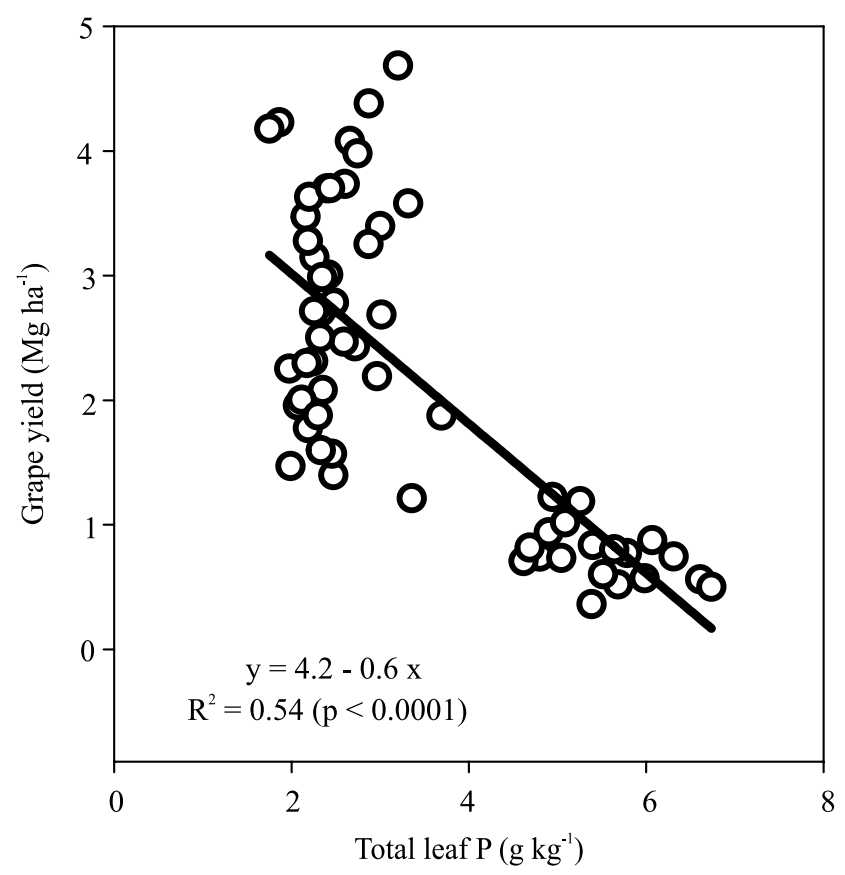

Figure 2. Linear regression between total phosphorus in leaves at flowering and grape yield of the 'Cabernet Sauvignon' grapevine (Vitis vinifera) grown in a Typic Humicryept subjected to the application of different $\mathrm{P}_{2} \mathrm{O}_{5}$ rates, in the municipality of Água Doce, in the state of Santa Catarina, Brazil.
(>4.0 $\mathrm{g} \mathrm{kg}^{-1}$ P) (Silva et al., 2016). These results are indicative that, in these conditions, the response to fertilization is small or almost null. Therefore, the application of amounts lower than $10 \mathrm{~kg} \mathrm{ha}^{-1} \mathrm{P}_{2} \mathrm{O}_{5}$ per year is recommended, considering the desired yields (Silva et al., 2016). It should be noted that only the mineralization of soil organic P can contribute this small amount of P to plants (Rita et al., 2013).

Grapevines typically present a vigorous root system in which more than $50 \%$ of the roots can be colonized with arbuscular mycorrhizal fungi (Schreiner, 2005), which increases P uptake efficiency. Part of the $\mathrm{P}$ absorbed by the roots and present within the grapevines returns to the soil: approximately $3.8 \mathrm{~kg}$ ha $^{-1} \mathrm{P}$ by senescent leaves (Schreiner, 2005) and around $1.5 \mathrm{~kg} \mathrm{ha}^{-1} \mathrm{P}$ by pruned branches deposited on the soil (Tecchio et al., 2011). Moreover, between 1.0 and 4.6 $\mathrm{kg} \mathrm{ha}^{-1} \mathrm{P}$ can be released during the decomposition of cover crop residues (Pérez-Álvarez et al., 2015). However, because part of the $\mathrm{P}$ absorbed annually by the grapevines can be accumulated in perennial organs, such as branches older than one year, stem, and especially roots, plant dependence on soil $\mathrm{P}$ is decreased (Piccin et al., 2017b).

In both experiments, there were no changes in yield or yield parameters (number of clusters, average cluster mass, cluster length, and cluster width) with the application of the studied $\mathrm{P}$ rates (Tables 1 and 2). These results support the hypothesis of the small dependence of the 'Cabernet Sauvignon' and 'Chardonnay' grapevines on the $\mathrm{P}$ applied under the edaphoclimatic conditions of the present study. Even with the increase in leaf $\mathrm{P}$ concentration, there was no increase in yield, particularly when concentrations in the leaf tissue were considered adequate (Ciotta et al., 2018). This is because total $P$ is measured in the tissue analysis, which is not always adequate, because part of the P may not be metabolic and, therefore, may be allocated to reserve organelles, such as the vacuole; this non-metabolic $\mathrm{P}$ represents an additional uptake stored for future use (Piccin et al., 2017b). To determine P forms in the tissue, which could be part of metabolic $P$, total $\mathrm{P}$ should not be used, but rather ribonucleic acids and soluble inorganic $\mathrm{P}$, since they may have a greater influence on grapevine yield parameters (Piccin et al., 2017a, 2017b). It was also observed that even when the soil in the area without $\mathrm{P}$ application was considered to have low or extremely low P availability (Silva et 
al., 2016), leaf $\mathrm{P}$ concentrations were interpreted as adequate. This supports the hypothesis that grapevines have mechanisms that increase P uptake efficiency, such as the increased growth of the root system into deeper soil layers (Mahmud et al., 2018), root association with arbuscular mycorrhizal fungi (Schreiner, 2005), and accumulation of internal reserves of $\mathrm{P}$ in perennial organs (Pradubsuk \& Davenport, 2010; Gautier et al., 2018).

As for the chemical composition of the must, differences in total soluble solids (TSS), total titratable acidity, $\mathrm{pH}$, and tartaric acid were observed between crop seasons for both cultivars (Tables 3 and 4). Data also showed that the grapes harvested in 2013/2014 were in a more advanced stage of maturity for both 'Cabernet Sauvignon' and 'Chardonnay'. The less rainy conditions during this development cycle in 2013/2014 (Figure 1) most likely allowed more time for the development of maturation indices.

The $\mathrm{P}$ rates hardly changed the composition of the must of the 'Cabernet Sauvignon' and 'Chardonnay' grapevines in all crop seasons. This shows that the $P$ rates had no effect on must composition under nonrestrictive conditions of water availability (Tables 3 and 4), which is possibly related to the high $\mathrm{P}$ adsorption capacity of the vineyard soils where the

Table 2. Soil available phosphorus and total leaf $\mathrm{P}$, number of clusters per plant, average cluster mass, yield, average cluster length, and average cluster width of 'Chardonnay' grapevines (Vitis vinifera) grown in a Typic Humicryept subjected to the application of different $\mathrm{P}_{2} \mathrm{O}_{5}$ rates, in the municipality of Água Doce, in the state of Santa Catarina, Brazil.

\begin{tabular}{|c|c|c|c|c|c|c|c|}
\hline \multirow[t]{2}{*}{ Variable } & \multicolumn{5}{|c|}{$\mathrm{P}_{2} \mathrm{O}_{5}\left(\mathrm{~kg} \mathrm{ha}^{-1}\right)$} & \multirow[t]{2}{*}{ Equation } & \multirow[t]{2}{*}{$\mathrm{R}^{2}$} \\
\hline & 0 & 10 & 20 & 40 & 80 & & \\
\hline \multicolumn{8}{|c|}{$2011 / 2012$ crop season } \\
\hline Soil available $P$ at flowering $\left(\mathrm{mg} \mathrm{kg}^{-1}\right)$ & 9.2 & 9.1 & 9.4 & 21.8 & 18.1 & $\mathrm{y}=9.25+0.14 \mathrm{x}$ & $0.29 *$ \\
\hline Soil available $P$ at veraison $\left(\mathrm{mg} \mathrm{kg}^{-1}\right)$ & - & - & - & - & - & - & - \\
\hline Total leaf $\mathrm{P}$ at flowering $\left(\mathrm{g} \mathrm{kg}^{-1}\right)$ & 2.6 & 3.0 & 4.0 & 4.2 & 5.0 & $\mathrm{y}=2.90+0.03 \mathrm{x}$ & $0.74 * *$ \\
\hline Total leaf $\mathrm{P}$ at veraison $\left(\mathrm{g} \mathrm{kg}^{-1}\right)$ & - & - & - & - & - & - & - \\
\hline Number of clusters per plant & 14 & 17 & 17 & 21 & 16 & - & ns \\
\hline Average cluster mass (g) & 290 & 300 & 293 & 326 & 282 & - & ns \\
\hline Yield $\left(\mathrm{Mg} \mathrm{ha}^{-1}\right)$ & 9.4 & 11.9 & 11.6 & 16.1 & 10.2 & - & ns \\
\hline Average cluster length $(\mathrm{cm})$ & 10.3 & 10.9 & 10.3 & 10.8 & 10.3 & - & ns \\
\hline Average cluster width $(\mathrm{cm})$ & 4.9 & 5.0 & 5.0 & 4.9 & 5.0 & - & ns \\
\hline \multicolumn{8}{|c|}{$2012 / 2013$ crop season } \\
\hline Soil available $P$ at flowering $\left(\mathrm{mg} \mathrm{kg}^{-1}\right)$ & 3.2 & 5.5 & 10.2 & 15.2 & 26.8 & $\mathrm{y}=3.26+0.30 \mathrm{x}$ & $0.96^{* *}$ \\
\hline Soil available $P$ at veraison $\left(\mathrm{mg} \mathrm{kg}^{-1}\right)$ & 3.5 & 3.7 & 6.2 & 10.6 & 12.4 & $y=3.64+0.12 x$ & $0.80 * *$ \\
\hline Total leaf $\mathrm{P}$ at flowering $\left(\mathrm{g} \mathrm{kg}^{-1}\right)$ & 4.0 & 4.0 & 5.4 & 5.6 & 6.1 & $y=4.19+0.03 x$ & $0.68^{* *}$ \\
\hline Total leaf $P$ at veraison $\left(\mathrm{g} \mathrm{kg}^{-1}\right)$ & 2.3 & 2.2 & 3.4 & 3.5 & 3.5 & $\mathrm{y}=2.49+0.02 \mathrm{x}$ & $0.34 * *$ \\
\hline Number of clusters per plant & - & - & - & - & - & - & - \\
\hline Average cluster mass (g) & - & - & - & - & - & - & - \\
\hline Yield $\left(\mathrm{Mg} \mathrm{ha}^{-1}\right)$ & - & - & - & - & - & - & - \\
\hline Average cluster length $(\mathrm{cm})$ & - & - & - & - & - & - & - \\
\hline Average cluster width $(\mathrm{cm})$ & - & - & - & - & - & - & - \\
\hline \multicolumn{8}{|c|}{$2013 / 2014$ crop season } \\
\hline Soil available $\mathrm{P}$ at flowering $\left(\mathrm{mg} \mathrm{kg}^{-1}\right)$ & 2.8 & 3.1 & 5.6 & 6.6 & 16.4 & $\mathrm{y}=1.78+0.17 \mathrm{x}$ & $0.94 * *$ \\
\hline Soil available $\mathrm{P}$ at veraison $\left(\mathrm{mg} \mathrm{kg}^{-1}\right)$ & 3.9 & 5.5 & 7.7 & 18.0 & 25.0 & $\mathrm{y}=3.55+0.28 \mathrm{x}$ & $0.95 * *$ \\
\hline Total leaf $\mathrm{P}$ at flowering $\left(\mathrm{g} \mathrm{kg}^{-1}\right)$ & 3.0 & 3.4 & 4.7 & 5.7 & 6.4 & $\mathrm{y}=3.32+0.04 x$ & $0.69 * *$ \\
\hline Total leaf $\mathrm{P}$ at veraison $\left(\mathrm{g} \mathrm{kg}^{-1}\right)$ & 2.2 & 2.1 & 2.6 & 3.4 & 3.2 & $\mathrm{y}=2.27+0.01 \mathrm{x}$ & $0.39 * *$ \\
\hline Number of clusters per plant & 16 & 18 & 16 & 17 & 14 & - & ns \\
\hline Average cluster mass (g) & 118 & 111 & 119 & 129 & 136 & - & ns \\
\hline Yield $\left(\mathrm{Mg} \mathrm{ha}^{-1}\right)$ & 4.5 & 4.7 & 4.4 & 5.0 & 4.5 & - & ns \\
\hline Average cluster length $(\mathrm{cm})$ & 11.6 & 10.0 & 11.0 & 11.3 & 12.0 & - & ns \\
\hline Average cluster width $(\mathrm{cm})$ & 6.5 & 5.6 & 5.6 & 6.9 & 6.9 & - & ns \\
\hline
\end{tabular}

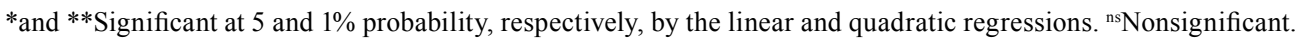


experiments were installed (Almeida et al., 2018). Therefore, rates higher than the values exported by the plants may not cause evident effects, as described in the literature (Silva et al., 2016).

TSS contents and $\mathrm{pH}$ values were not affected by the $\mathrm{P}$ rates applied to the soil in the 'Cabernet Sauvignon' vineyard. For this cultivar, total titratable acidity and tartaric acid concentrations showed a decreasing trend with increasing $\mathrm{P}$ rates, with significant differences only in 2013/2014 (Table 3 ). The decrease in total titratable acidity was 0.24 meq $\mathrm{L}^{-1}$ for each kilogram of $\mathrm{P}_{2} \mathrm{O}_{5}$ applied to the soil; however, the decrease in tartaric acid in the must was only 0.002 meq $\mathrm{L}^{-1}$ for each kilogram of $\mathrm{P}_{2} \mathrm{O}_{5}$ applied. This behavior was also shown in the data collected by Piccin et al. (2017a), who did not identify a significant variation in the soluble solids contents, $\mathrm{pH}$, and total titratable acidity of the studied grapes. However, these authors found important variations in phenolic composition - especially in total polyphenols and total anthocyanins - in relation to the $\mathrm{P}$ rates applied to the vineyard.

For 'Chardonnay', the increasing $\mathrm{P}$ rates only increased the TSS contents of the must in 2011/2012 (Table 4). TSS values increased up to an estimated rate of $44 \mathrm{~kg} \mathrm{ha}^{-1} \mathrm{P}_{2} \mathrm{O}_{5}$ in this crop season, with an estimated maximum value of $18.03^{\circ}$ Brix (Table 4). For this cultivar, there was a decreasing trend in total titratable acidity and tartaric acid concentration with increasing $\mathrm{P}$ rates, but an increasing one in $\mathrm{pH}$, with significant differences only in 2011/2012. This behavioral trend in $\mathrm{pH}$ and total titratable acidity values was also observed by Piccin et al. (2017a) for the 'Tannat' and 'Cabernet Franc' grapevines ( $V$. vinifera), with significant differences. These results are most likely due to the greater $\mathrm{P}$ movement in the plant at flowering and veraison, as shown by the increase in leaf $P$ concentration with increasing $P$ rates applied to the soil (Table 2). Therefore, although the supplementation with mineral $\mathrm{P}$ promoted the nutritional improvement of the grapevine, it did not significantly improve grape quality. Čoga et al. (2009) found a significant correlation between leaf $\mathrm{P}$ concentration and grape maturation, with an increase in the sugar concentration and a reduction in the total titratable acidity of the must with increasing leaf $\mathrm{P}$ concentration. According to other authors, must composition is affected by $\mathrm{P}$ concentration, without influencing volatile grape compounds (Yuan et al., 2018) at the fermentation stage (Schreiner \& Osborne, 2018).

Table 3. Must composition of the 'Cabernet Sauvignon' grapevine (Vitis vinifera) grown in a Typic Humicryept subjected to the application of different $\mathrm{P}_{2} \mathrm{O}_{5}$ rates, in the municipality of Água Doce, in the state of Santa Catarina, Brazil.

\begin{tabular}{|c|c|c|c|c|c|c|c|}
\hline \multirow[t]{2}{*}{ Variable } & \multicolumn{5}{|c|}{$\mathrm{P}_{2} \mathrm{O}_{5}\left(\mathrm{~kg} \mathrm{ha}^{-1}\right)$} & \multirow[t]{2}{*}{ Equation } & \multirow[t]{2}{*}{$\mathrm{R}^{2}$} \\
\hline & 0 & 10 & 20 & 40 & 80 & & \\
\hline \multicolumn{8}{|c|}{ 2011/2012 crop season } \\
\hline Total soluble solids ( $\left.{ }^{\circ} \mathrm{Brix}\right)$ & 17.1 & 17.1 & 17.0 & 16.5 & 16.3 & - & $\mathrm{ns}$ \\
\hline $\mathrm{pH}$ & 3.21 & 3.17 & 3.22 & 3.19 & 3.19 & - & $\mathrm{ns}$ \\
\hline Total titratable acid (meq $\left.\mathrm{L}^{-1}\right)$ & 153.5 & 165.5 & 135.5 & 144.0 & 137.5 & - & $\mathrm{ns}$ \\
\hline Tartaric acid $\left(m e q L^{-1}\right)$ & 1.15 & 1.24 & 1.02 & 1.08 & 1.03 & - & $\mathrm{ns}$ \\
\hline \multicolumn{8}{|c|}{$2012 / 2013$ crop season } \\
\hline Total soluble solids ( $\left.{ }^{\circ} \mathrm{Brix}\right)$ & 15.7 & 16.6 & 16.3 & 16.0 & 15.0 & - & ns \\
\hline $\mathrm{pH}$ & 2.99 & 3.01 & 3.07 & 3.04 & 3.01 & - & ns \\
\hline Total titratable acid (meq $\left.\mathrm{L}^{-1}\right)$ & 217.0 & 209.0 & 196.5 & 197.5 & 187.0 & - & ns \\
\hline Tartaric acid $\left(\right.$ meq L $\left.{ }^{-1}\right)$ & 1.63 & 1.57 & 1.47 & 1.48 & 1.40 & - & $\mathrm{ns}$ \\
\hline \multicolumn{8}{|c|}{ 2013/2014 crop season } \\
\hline Total soluble solids ( $\left.{ }^{\circ} \mathrm{Brix}\right)$ & 19.4 & 19.1 & 19.4 & 19.4 & 19.4 & - & ns \\
\hline $\mathrm{pH}$ & 3.29 & 3.27 & 3.41 & 3.32 & 3.30 & - & $\mathrm{ns}$ \\
\hline Total titratable acid (meq L $\left.{ }^{-1}\right)$ & 144.4 & 141.0 & 123.0 & 129.5 & 122.3 & $y=139.30-0.24 x$ & $0.28 *$ \\
\hline Tartaric acid (meq L-1) & 1.08 & 1.06 & 0.92 & 0.97 & 0.92 & $y=1.04-0.002 x$ & $0.28^{*}$ \\
\hline
\end{tabular}

* and ${ }^{* *}$ Significant at 5 and $1 \%$ probability, respectively, by the linear and quadratic regressions. ${ }^{\text {ns }}$ Nonsignificant. 
Table 4. Must composition of the 'Chardonnay' grapevine (Vitis vinifera) grown in a Typic Humicryept subjected to the application of different $\mathrm{P}_{2} \mathrm{O}_{5}$ rates, in the municipality of Água Doce, in the state of Santa Catarina, Brazil.

\begin{tabular}{|c|c|c|c|c|c|c|c|}
\hline \multirow{2}{*}{ Variable } & \multicolumn{5}{|c|}{$\mathrm{P}_{2} \mathrm{O}_{5}\left(\mathrm{~kg} \mathrm{ha}^{-1}\right)$} & \multirow[t]{2}{*}{ Equation } & \multirow[t]{2}{*}{$\mathrm{R}^{2}$} \\
\hline & 0 & 10 & 20 & 40 & 80 & & \\
\hline \multicolumn{8}{|c|}{ 2011/2012 crop season } \\
\hline Total soluble solids ( $\left.{ }^{\circ} \mathrm{Brix}\right)$ & 16.0 & 17.6 & 18.2 & 17.6 & 17.6 & $y=16.50+0.07 x-0.0008 x^{2}$ & $0.36^{*}$ \\
\hline $\mathrm{pH}$ & 3.36 & 3.35 & 3.41 & 3.40 & 3.44 & $y=3.36+0.001 x$ & $0.29 *$ \\
\hline Total titratable acid (meq L-1) & 97.0 & 94.5 & 83.0 & 85.5 & 85.5 & - & ns \\
\hline Tartaric acid $($ meq L-1) & 0.73 & 0.71 & 0.62 & 0.64 & 0.64 & - & $\mathrm{ns}$ \\
\hline \multicolumn{8}{|c|}{ 2013/2014 crop season } \\
\hline Total soluble solids ( $\left.{ }^{\circ} \mathrm{Brix}\right)$ & 20.4 & 20.1 & 20.7 & 19.9 & 19.9 & - & ns \\
\hline $\mathrm{pH}$ & 3.45 & 3.42 & 3.47 & 3.48 & 3.50 & - & $\mathrm{ns}$ \\
\hline Total titratable acid (meq L $\left.\mathrm{L}^{-1}\right)$ & 118.3 & 105.9 & 106.5 & 110.6 & 108.3 & - & $\mathrm{ns}$ \\
\hline Tartaric acid $($ meq L-1) & 0.89 & 0.79 & 0.80 & 0.83 & 0.81 & - & $\mathrm{ns}$ \\
\hline
\end{tabular}

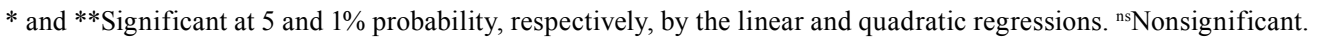

\section{Conclusion}

Phosphorus application in the soil increases the contents of available phosphorus, but does not result in higher yields of the Cabernet Sauvignon and Chardonnay grapevine (Vitis vinifera) cultivars.

\section{Acknowledgments}

To Conselho Nacional de Desenvolvimento Científico e Tecnológico (CNPq), for supporting the productivity grant for the fourth author.

\section{References}

ALMEIDA, J.A. de; CORREA, J.; SCHMITT, C. Clay mineralogy of basaltic Hillsides in the western state of Santa Catarina. Revista Brasileira de Ciência do Solo, v.42, e0170086, 2018. DOI: https://doi.org/10.1590/18069657rbcs20170086.

BONFATTI, B.R.; HARTEMINK, A.E.; GIASSON, E.; TORNQUIST, C.G.; ADHIKARI, K. Digital mapping of soil carbon in a viticultural region of Southern Brazil. Geoderma, v.261, p.204-221, 2016. DOI: https://doi.org/10.1016/j. geoderma.2015.07.016.

BRIGHENTI, A.F.; BRIGHENTI, E.; BONIN, V.; RUFATO, L. Caracterização fenológica e exigência térmica de diferentes variedades de uvas viníferas em São Joaquim, Santa Catarina - Brasil. Ciência Rural, v.43, p.1162-1167, 2013. DOI: https://doi.org/10.1590/S0103-84782013005000082.

CIOTTA, M.N.; CERETTA, C.A.; FERREIRA, P.A.; STEFANELLO, L.O.; COUTO, R. da R.; TASSIANRI, A.; MARCHEZAN, C.; GIROTTO, E.; CONTI, L. de; LOURENZI, C.R.; BRUNETTO, G. Phosphorus fertilization for young grapevines of Chardonnay and Pinot Noir in sandy soil. IDESIA, v.36, p.27-34, 2018.

ČOGA, L.; SLUNJSKI, S.; ĆUSTIĆ, M.H.; MASLAĆ, J.; PETEK, M.; ĆOSIĆ, T.; PAVLOVIĆ, I. Influence of soil reaction on phosphorus, potassium, calcium and magnesium dynamics in grapevine (Vitis vinifera L.). Agriculturae Conspectus Scientificus, v.74, p.39-43, 2009.

FERREIRA, D.F. Programa de análises estatísticas (Statistical Analysis Software) e planejamento de experimentos. Lavras: UFLA, 2003.

GAUTIER, A.; COOKSON, S.J.; HEVIN, C.; VIVIN, P.; LAUVERGEAT, V.; MOLLIER, A. Phosphorus acquisition efficiency and phosphorus remobilization mediate genotypespecific differences in shoot phosphorus content in grapevine. Tree Physiology, v.38, p.1742-1751, 2018. DOI: https://doi.org/10.1093/treephys/tpy074.

MAHMUD, K.P.; SMITH, J.P.; ROGIERS, S.Y.; GUISARD, Y.; NIELSON, S.; HOLZAPFEL, B.P. Diurnal root growth dynamics in mature grapevines. Acta Horticulturae, v.1205, p.555-562, 2018. DOI: https://doi.org/10.17660/ActaHortic.2018.1205.70.

MURPHY, J.; RILEY, J.P. A modified single solution method for the determination of phosphate in natural waters. Analytica Chimica Acta, v.27, p.31-36, 1962.

OLIVEIRA, C.M.B. de; GATIBONI, L.C.; MIQUELLUTI, D.J.; SMYTH, T.J.; ALMEIDA, J.A. Capacidade máxima de adsorção de fósforo e constante de energia de ligação em latossolo bruno em razão de diferentes ajustes do modelo de langmuir. Revista Brasileira de Ciência do Solo, v.38, p.1805-1815, 2014. DOI: https://doi.org/10.1590/S0100-06832014000600015.

PÉREZ-ÁLVAREZ, E.P.; GARCÍA-ESCUDERO, E.; PEREGRINA, F. Soil nutrient availability under cover crops: effects on vines, must, and wine in a Tempranillo vineyard. American Journal of Enology and Viticulture, v.66, p.311-320, 2015. DOI: https://doi.org/10.5344/ajev.2015.14092. 
PICCIN, R.; COUTO, R. da R.; BELLINASO, R.J.S.; GATIBONI, L.C.; DE CONTI, L.; RODRIGUES, L.A.T.; SOMAVILLA, L.M.; KULMANN, M.S. de S.; BRUNETTO, G. Phosphorus forms in leaves and their relationships with must composition and yield in grapevines. Pesquisa Agropecuária Brasileira, v.52, p.319-327, 2017a. DOI: https://doi.org/10.1590/S0100-204X2017000500005.

PICCIN, R.; KAMINSKI, J.; CERETTA, C.A.; TIECHER, T.; GATIBONI, L.C.; BELLINASO, R.J.S.; MARCHEZAN, C.; SOUZA, R.O.S. de; BRUNETTO, G. Distribution and redistribution of phosphorus forms in grapevines. Scientia Horticulturae, v.218, p.125-131, 2017b. DOI: https://doi.org/10.1016/j.scienta.2017.02.023.

PONI, S.; GATTI, M.; PALLIOTI, A.; DAI, Z.; DUCHÊNE, E.; TRUONG, T.-T.; FERRARA, G.; MATARRESE, A.M.S.; GALLOTA, A.; BELLINCONTRO, A.; MENCARELLI, F.; TOMBESI, S. Grapevine quality: a multiple choice issue. Scientia Horticulturae, v.234, p.445-462, 2018. DOI: https://doi.org/10.1016/j.scienta.2017.12.035.

PRADUBSUK, S.; DAVENPORT, J.R. Seasonal uptake and partitioning of macronutrients in mature 'Concord' grape. Journal of the American Society for Horticultural Science, v.135, p.474483, 2010. DOI: https://doi.org/10.21273/JASHS.135.5.474.

RITA, J.C. de O.; GAMA-RODRIGUES, A.C.; GAMARODRIGUES, E.F.; ZAIA, F.C.; NUNES, D.A.D. Mineralization of organic phosphorus in soil size fractions under different vegetation covers in the North of Rio de Janeiro. Revista Brasileira de Ciência do Solo, v.37, p.1207-1215, 2013. DOI: https://doi.org/10.1590/S0100-06832013000500010.

SANTOS, H.G. dos; JACOMINE, P.K.T.; ANJOS, L.H.C. dos; OLIVEIRA, V.Á. de; LUMBRERAS, J.F.; COELHO, M.R.; ALMEIDA, J.A. de; CUNHA, T.J.F.; OLIVEIRA, J.B. de. Sistema brasileiro de classificação de solos. 3.ed. rev. e ampl. Brasília: Embrapa, 2013. 353p.

SCHMITT, D.E.; BRUNETTO, G.; SANTOS, E. dos; WAGNER, W. de L.; SETE, P.B.; SOUZA, M.; AMBROSINI, V.G.; SANTOS, M.A. dos; TIECHER, T.; COMIN, J.J.; COUTO, R. da R.; GATIBONI, L.C.; GIACHINI, A. Phosphorus fractions in apple orchards in southern Brazil. Bragantia, v.76, p.422-432, 2017. DOI: https://doi.org/10.1590/1678-4499.173.
SCHREINER, R.P. Spatial and temporal variation of roots, arbuscular mycorrhizal fungi, and plant and soil nutrients in a mature Pinot Noir (Vitis vinifera L.) vineyard in Oregon, USA. Plant and Soil, v.276, p.219-234, 2005. DOI: https://doi.org/10.1007/s11104-005-4895-0.

SCHREINER, R.P.; LEE, J.; SKINKIS, P.A. N, P, and K supply to Pinot noir grapevines: impact on vine nutrient status, growth, physiology, and yield. American Journal of Enology and Viticulture, v.64, p.26-38, 2013. DOI: https://doi.org/10.5344/ ajev.2012.12064.

SCHREINER, R.P.; OSBORNE, J. Defining phosphorus requirements for Pinot Noir grapevines. American Journal of Enology and Viticulture, v.69, p.351-359, 2018. DOI: https://doi.org/10.5344/ajev.2018.18016.

SILVA, L.S.; GATIBONI, L.C.; ANGHINONI, I.; SOUZA, R.O. (Ed.). Manual de calagem e adubação para os estados do Rio Grande do Sul e de Santa Catarina. 11.ed. [Xanxerê]: Comissão de Química e Fertilidade do Solo - RS/SC, 2016. 376p.

SIMÕES NETO, D.E.; OLIVEIRA, A.C. de; FREIRE, F.J.; FREIRE, M.B.G. dos S.; NASCIMENTO, C.W.A. do; ROCHA, A.T. da. Extração de fósforo em solos cultivados com canade-açúcar e suas relações com a capacidade tampão. Revista Brasileira de Engenharia Agrícola e Ambiental, v.13, p.840-848, 2009. DOI: https://doi.org/10.1590/S1415-43662009000700005.

SOIL SURVEY STAFF. Keys to soil taxonomy. $11^{\text {th }}$ ed. Washington: USDA, NRCS, 2010.

TECCHIO, M.A.; TEIXEIRA, L.A.J.; TERRA, M.M.; MOURA, M.F.; PAIOLI-PIRES, E.J. Extração de nutrientes pela videira 'Niagara Rosada' enxertada em diferentes porta-enxertos. Revista Brasileira de Fruticultura, v.33, p.736-742, 2011. Número especial. DOI: https://doi.org/10.1590/S0100-29452011000500103.

TEDESCO, M.; GIANELLO, C.; BISSANI, C.A. BOHNEN, H.; VOLKWEISS, S.J. Análise de solo, plantas e outros materiais. 2.ed. rev. e ampl. Porto Alegre: UFRGS, 1995.

YUAN, F.; SCHREINER, R.P.; QIAN, M.C. Soil nitrogen, phosphorus, and potassium alter $\beta$-damascenone and other volatiles in Pinot Noir berries. American Journal of Enology and Viticulture, v.69, p.157-166, 2018. DOI: https://doi.org/10.5344/ ajev.2017.17071. 